\title{
Mining damage management system with a stakeholder communication component
}

\author{
Katarzyna Styk, Paweł Bogacz \\ Faculty of Mining and Geoengineering, University of Science and Technology, Cracow, Poland
}

\begin{abstract}
The paper presents an original algorithmfor a mining damage management system with a stakeholder communication component.The paper addresses the issue of communication with stakeholders of mining companies, more specifically, with local stakeholders (hosts) who face the problem of damage caused by the mining activities of companies. Efficient and effective communication in case of occurrence and reporting of damages is extremely important for the image and quality of relations with local communities. However, there is an apparent problem in the industry with the speed and efficiency of processing claims. The authors of the paper propose a procedural model to improve this process. The algorithm is based on the Servqual methodology, with parallel accounting,according to the project management triangle, of the elements of scope, finance, time, and quality. The algorithm is fully functional and comprehensive. Not only does it guide through the next steps, indicating times and personal responsibility, but it also includes draft input and output documents. It provides an effective guide for the conduct of each notification, describing the course of actions and indicating the necessary actions to be taken.
\end{abstract}

\section{Introduction}

Over the years the approach of investors to data presented by companies has changed. Initially, only profit counted, i. e., material factors. For the past two thousand years, an approach focused on intangible assets has been gainingpopularity, and now, after almost twenty centuries, it is the main approach used by shareholders. Intangible assets are the key factor in the competitive advantage of companies, especially those with a large pool of knowledge and know-how. They include stakeholder relations, organizational culture, management style, human resources, and communication. The elements mentioned above directly fit into the concept of corporate social responsibility, the concept of functioning of enterprises, according to which they implement their strategies taking into account social and environmental aspects, putting particular emphasis on these factors in their commercial activities and their contacts with stakeholders. Undertaking socially responsible actions focused on human resources, environmental issues, and maintaining good relations with stakeholders, as well as providing information on the actions taken contributes directly to the increase in value and thus competitiveness of the enterprise. Undertaking socially responsible actions, including the involvement of stakeholders in the process of building corporate strategy, is extremely important, especially for industries struggling with 
difficulties in social acceptance. An ideal example of such an industry is mining in its broadest sense.

The mining and quarrying industry is extremely important to society, but companies mustremember that they must act in the socially responsible way mentioned above - from supporting the promotion of sustainable economic growth and building resilient and inclusive communities to introducing the innovations necessaryto address the urgent need for climate change. The International Council on Mining and Metals (ICMM) is strongly committed to ethical business practices that support the sustainable development of industrial enterprises.

Responding to the expectations of the industry and business stakeholders, as well as based on the values and good practices of companies, ICMM has prepared the so-called "European Commission Mining Rules," which are a set of environmental, social, and governance requirements and challenges for businesses, which in their turn will support progress towards the implementation of the global sustainable development goals of the UN and the Paris Climate Agreement. The ICMM's mining rules aim to maximize the benefits of the industry for local stakeholders while minimizing negative impacts to effectively manage social issues. The ICMM has distinguished ten principles:

- $\quad$ Ethical business - apply ethical business practices and sound systems of corporate governance and transparency to support sustainable development

- Decision-making - integrate sustainable development in corporate strategy decision-making process

- Human rights - respect human rights and the interests, cultures, customs and values of employees and communities affected by our activities

- Risk management - implement effective riskmanagement strategies and systems that are based on sound science and incorporate stakeholder perceptions of risk

- Health and safety - pursue continual improvement in the health and safety performance with the ultimate goal of zero harm

- Environmental performance - pursue continuous improvement in environmental indicators, such as water management, energy consumption, and climate change

- Conservation of biodiversity - contribute to the conservation of biodiversity and integrated approaches to land-use planning

- Responsible production - facilitate and support the knowledgebase and systems for responsible design, use, recycling, and disposal of products containing metals and minerals

- Social performance - pursue continual improvement in social performance and contribute to the social, economic, and institutional development of host communities

- Stakeholder engagement - proactively engage key stakeholders on sustainable development challenges and opportunities in an open and transparent manner, effectively report and independently verify progress and performance.

Based on the experience of not only companies and stakeholders but also NGOs and scientists, the ICMMhas identified four expectations for social outcomes. They are presented in Table 1. 
Table 1. ICMM's expectations of social performance.

\begin{tabular}{|r|r|r|}
\hline 1 & $\begin{array}{l}\text { Support the } \\
\text { development of the local } \\
\text { community }\end{array}$ & $\begin{array}{l}\text { Takean inclusive approach to local communities to identify } \\
\text { their development priorities and support activities that } \\
\text { contribute to their sustainable social and economic well-being, } \\
\text { in cooperation, with government, civil society and } \\
\text { development agencies, where appropriate. }\end{array}$ \\
\hline 2 & $\begin{array}{l}\text { Support the } \\
\text { development of the local } \\
\text { economy }\end{array}$ & $\begin{array}{l}\text { Enabling local businesses to access procurement and } \\
\text { contracting opportunities throughout the project lifecycle, both } \\
\text { directly and by encouraging larger contractors and suppliers, as } \\
\text { well as by supporting initiatives that enhance economic } \\
\text { opportunities for local communities. }\end{array}$ \\
\hline 3 & $\begin{array}{l}\text { Involve stakeholders based on an analysis of the local } \\
\text { context and provide local stakeholders with access to effective } \\
\text { mechanisms for seeking solutions to complaints related to the } \\
\text { company and its activities. }\end{array}$ \\
\hline $\begin{array}{l}\text { Involvement } \\
\text { problems in artakeholders } \\
\text { mining }\end{array}$ & $\begin{array}{l}\text { Where appropriate, work with the government to promote } \\
\text { environmental and social improvements in local craft and } \\
\text { small-scale living practices (ASM). }\end{array}$ \\
\hline
\end{tabular}

Source: own study based onthe ICMM website.

From the information presented above, it follows that to build an effective strategy of the enterprise and ensure competitive advantages, it is necessary to include local stakeholders of the enterprise in the undertaken activities. Therefore, the authors of this article have undertaken work thatresulted in the creation of a management system for theeliminationof mining damages with a stakeholder communication component. The effects of the work are presented in the following chapterspreceded by chapters presenting the methodological and conceptual context for the proposed original solutions.

\section{Relational Models As The Basis For Building A Modern Business Management Methodology}

The growing supply of consumer (B2C) and industrial (B2B) products observed for the past few decades, increasing globalization and the resultant competition forced many companies to undertake actions aimed at defending their market positions. Two lines of action were developed: restructuring and intensification of marketing activities.

Changes within a company involve mostly technical, financial, and organisational restructuring (described in numerous publications, for example [1,2]. The goal is to increase effectiveness and create a clear organisational structure allowing for reliable and fast exchange of information. The result of such changes can be summarised as increasing the effectiveness of managing the company's raw materials.

The second approach focuses on deep market penetration and a thorough search for and effective management of an attractive group of customers, with management componentsof other stakeholder groups, especially hosts (local communities, local NGOs, etc). A properly targeted marketing results in increased sales, whereas full control over marketing expenses ensures an increase in the profitability of the company.

Within the group of market-related activities, competition has forced companies to change their operating philosophy from initial production-sales (transactional) to relational, and often even further, to the concept of sustainable development.

The construction of the concept of relational marketing and sustainability has revolutionized the way we perceive the market and build our position in contacts with customers and other stakeholders. Withthe development of the information society [3] and the so-called knowledge-based economy [4], it turned out that the transactional marketing 
concept built by Culliton in 1948 [5], and expansion to the strategic form of 4P in 1964 by Borden (Borden, 1964), did not fully reflect the essence of building lasting and profitable ties with the market. It was in response to these needs that the concept of relational marketing, also known as affiliate marketing, appeared. Its creator is Ch. Gronroos [6], who presents it as "Profitably building, maintaining and developing relationships with consumers and other partners in the implementation of mutual goals of allparties, through the exchange of values and fulfillment of obligations." The first applicationof this concept appeared in service companies [7], but in 1983 it was adapted to the marketing of industrial products (IBM implementations) after [8]. The development of relational marketing concepthas led to the extension of its definition to the notion "Understanding and anticipating the needs of consumers, integrating the resources, means, and activities of an organization to profitably and efficiently deliver and communicate relevant goods and services more effectively than competing organizations" [9] and the final formula 5I (Identification, Individualization, Interaction, Integration, Integrity) [10].

In a broader, general, and stakeholder-related scope, the concept of relational marketing was proposedby the United Nations Organization, which in 1992 indicated it as part of the overarching thesis of sustainable development (UN 1992): a society that wants to implement the concept of sustainable development must recognize the supremacy of environmental and sociological requirements, which shall notbe disturbed by the economy and economic growth of civilization.

Within relational marketing, three main sub-processes (stages) can be identified, as is schematically shown in Figure 1.

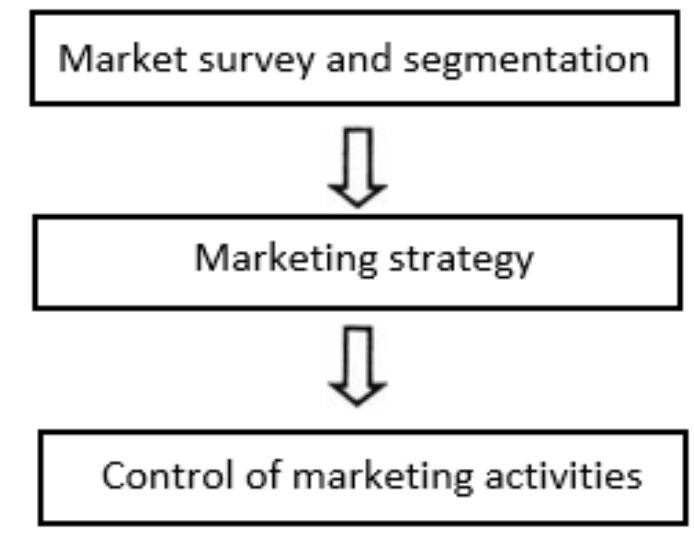

Fig.1 The process of relational marketing Developed by authors.

Using market research, segmenting theminto profitable sectors (objects), developing multi-level marketing strategies, and controlling the effectiveness of the decisions made (Fig. 1), relational marketing enables creating long-term and profitable relationships with customers.

According to this approach, the customersareasked to specify theirneeds while at the same time theirmarket attractiveness for the company is assessed. The findings are used to construct a differentiated system of marketing (targeted at sectors, customer groups), and after its introduction, controls are used to measure its effectiveness.

This process leads to the integration of the goals and work of the supplier and the customer or other stakeholder and, as a consequence, creates the so-called profit by satisfaction. The main difference between this category of profit and profits through sales, 
classically understood by the previous concept of transactional marketing, is the greater durability of profits, which happens thanks to satisfaction. It is associated with the high loyalty of the satisfied customer generating them. This issue is presented in Figure 2 in detail.
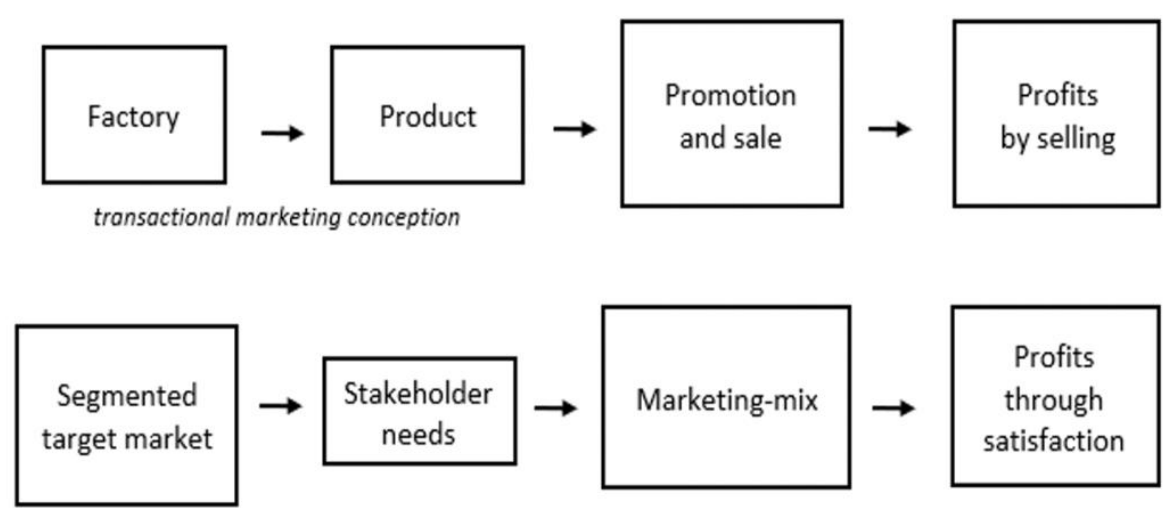

relationships marketing conception

Fig. 2. Differences between the concept of transactional marketing and the concept of relational marketing Developed by authors.

Taking into account the lineof sustainable development, starting from the concept of relational marketing, the algorithm shown in Figure 3 was built.

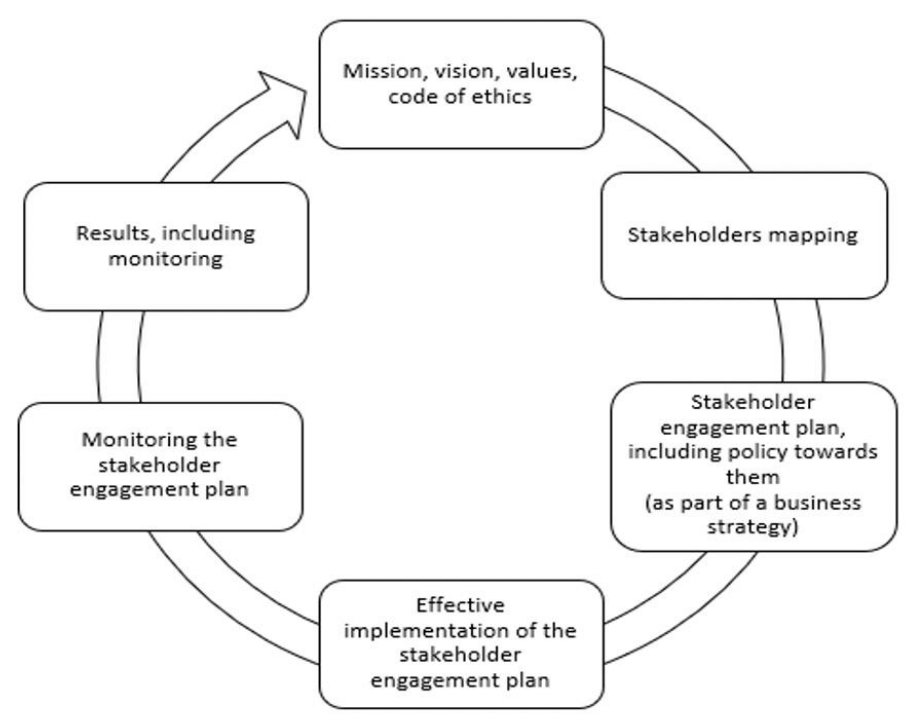

Fig. 3. Algorithm of sustainable development Developed by authors.

As Figure 3 shows, the principle of this relational process is very similar to that of relational marketing. Based on the elements of the company's mission, vision, and values, the stakeholder mapping process is then carried out, and on this basis, plans for their involvement are created. Subsequent activities related to sustainable development concern the effective implementation of these plans and then their monitoring and reporting. 


\section{The role of relational models in the management of a modern company in the mining industry}

The above-presented competitive situation and the method of marketing management with the use of relationship marketing or sustainable development have also been appliedin Poland for the last thirty years. This is, of course, is related to its entry into the realities of a free market economy. In the case of many industries, it was possible to quickly make up for several dozen years of backlog in the style of company (micro) and market (macro) management. However, there are sectors in which, unfortunately, there still are backlogs in planning, implementing, and conducting activities in the relational marketing system. One of them is mining. While extensive restructuring activities have been carried out in this sector since 1992 [11], aimed at adapting the industry to the realities of competitiveness, globalization, and fast communication, its market activities are, unfortunately, often built in an incomplete, discontinuous manner, often uncoordinated at the ownership (state) level, and, above all, without the use of the market research model described above in relational marketing or sustainable development, allowing for better identification of the client or stakeholder and their needs and adapting to the received image the appropriate strategy of activities, including distribution. There are still many voices pointing out that there is no place for marketing in such a specific industry, and that long-term contracts, high barriers to entry into the industry, and the high and, many believe, the unquestionable price competitiveness of mining products, do not require "marketing support" to do so(for example http://nettg.pl/Śląsk, węgiel,praca).

The authors of this work cannot agree with the above opinions. One of theme wrote about this many times [12-14], thus referring to a group of many other experts from the distant and more recent past, including [15-19]. The authors of this work believe that the mining products market is subject to normal market rules, and the product marketing management process cannot end at the level of selling it to the next link in the logistics chain. It is all the more important as the competitive situation of this product for the Polish manufacturer has changed significantly in recent years.

To help the mining industry in the most effective and early implementation of relational actions in the strategic and operational activities of mining companies, in the following chapters of this article, they presented a set of proposals for building one of the components of such a relational system, namely the crisis management component. In this matter, it was based on the authors' experiences and proposals presented in previous works [20-22], as well as on benchmarks prepared by members the International Council on Mining and Metals (ICMM).

The authors' interest in crisis management was related to the issue of mining damage, which is essential for mining, especially underground mining. The legal starting point for dealing with this matter by the authors was the provisions of the Polish Geological and Mining Law of June 9, 2011, after its amendment of January 1, 2019. Its Section VIII covers issues related to the regulation of liability for mining damages. Art. 144.1 of the above document indicates that "The owner may not oppose the threats caused by the operation of the mining plant, which is operated in accordance with the Act. He may, however, demand compensation for the damage caused by this operation, on the terms set out in the Act".

Given the above aspect, as well as the issue of the speed of occurrence of possible complaints and their causal relationship inherent in the damage to the mining enterprise, the effective handling of this issue by the mining enterprise should, in the authors' opinion, be a crisis component of the relational system of the mining enterprise. The above is all the more important as the Geological and Mining Law in Poland requires that mining damage should be considered in the first place in a conciliatory system and be taken to court only if 
this method is exhausted. This is described in detail in Art. 151.1: "Court redress is possible after the settlement procedure has been exhausted. The condition of exhausting the settlement procedure is met if the entrepreneur has refused to conclude a settlement or if 30 days have elapsed since the aggrieved party has filed a claim against the entrepreneur unless the aggrieved party sets a longer period when submitting a request for a settlement". The starting point for determining the types of damage being the subject of the analysis were the results of the research by Sobula, Martyka, and Nowak entitled "Mining damage as an element of discomfort in the living conditions of the inhabitants of Upper Silesia", which collected the opinions of 500 inhabitants of the cities of the Silesian Voivodeship around which mining activities are conducted. Among the many types of research, the authors of that study also dealt with the analysis of the types of mining damage, starting from the injured side, and not the statistics and nomenclature used by mining enterprises. In this way, various types of mining damage were collected and summarized in the mining areas of the Upper Silesian Coal Basin, located in southern Poland. They are shown in Figure 4.

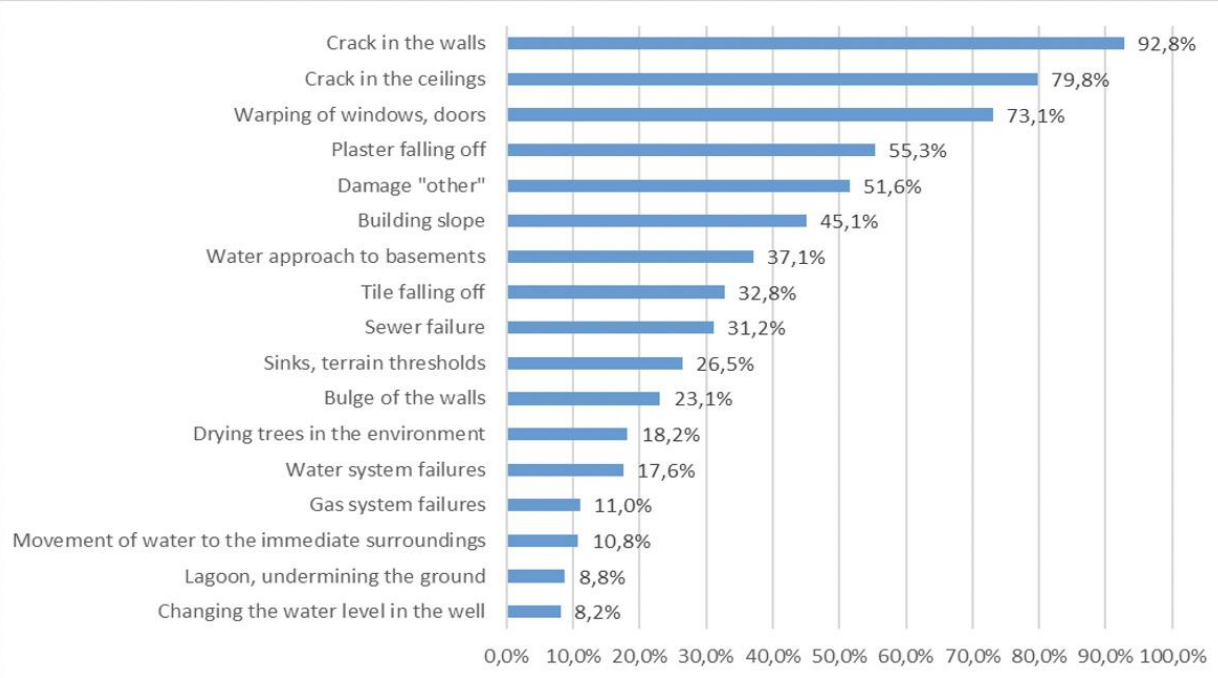

Fig. 4. Types of mining damage and their amount according to the study Mining damage as an element of discomfort in the living conditions of the inhabitants of Upper Silesia [\% of answers in a group of 500 people] Source: Own study based on Sobula, Martyka, Nowak.

The basic element of any crisis management system is setting a schedule for its implementation. The primary subject of circulation in this schedule is a stakeholder complaint. The speed of its circulation indicates the effectiveness of the mining company's communication with its stakeholders, which in this element is additionally highlighted by the increased level of the stakeholder needs, resulting from the most common sudden problem and its very negative connotation, the potential causes of which lie precisely in the mining company.

The scale of this type of problem is well evidenced by the results of the abovementioned research by Sobula, Martyka, and Nowak entitled "Mining damage as an element of discomfort in the living conditions of the inhabitants of Upper Silesia". Among many issues, the time from reporting the case to repairing the damage was also investigated. The results of these tests are shown in Figure 5. 


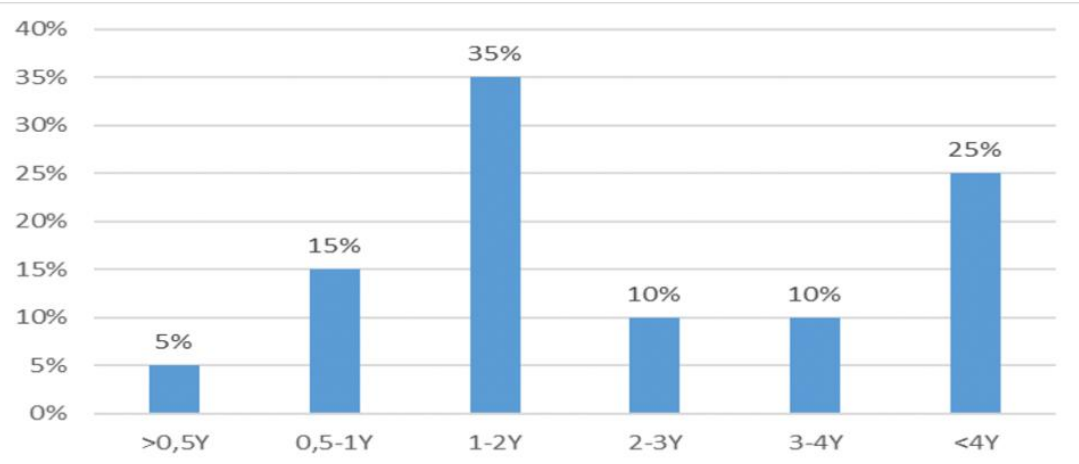

Fig. 5. Times for mining enterprises to consider complaints of their stakeholders in relation to mining damage in the Upper Silesian Coal Basin Source: Own study based on Sobul, Martyka, Nowak.

As shown in Figure 5, the average duration of a complaint in the Upper Silesian Coal Basin was 1.5 years. About $35 \%$ of cases are processed within 1-2 years. However, as many as $25 \%$ of complaints have been conducted for a period exceeding 4 years. These results are very negative, undoubtedly thus affecting the perception and level of the stakeholder relationship with mining enterprises.

For the above reason, it should be assumed that the circulation of such a complaint in the system should have the highest possible efficiency, the measurement of which will be based on the processing time of such a complaint. With such a system, it will also be possible to check at any time at what stage such a complaint is at, to analyze the duration of individual actions and decisions taken, and in the case of exceeding the expected time frame, to draw conclusions about the reasons for this state of affairs.

\section{A management system for algorithms to eliminate mining damage with a stakeholder communication component}

Within the framework of the authors' project of building a management system of elimination mining damages with a stakeholder communication component, the work was divided into four stages:

- Identification of local stakeholder groups

- Identification of infrastructure and possible damage

- Development of the design of a complaints algorithm for local stakeholders

- Creation of the scheme of elimination of the detected mining damage.

\subsection{Identification of local stakeholder groups}

The process of identifying existing stakeholder groups consists of five steps, as shown in Figure 6. 


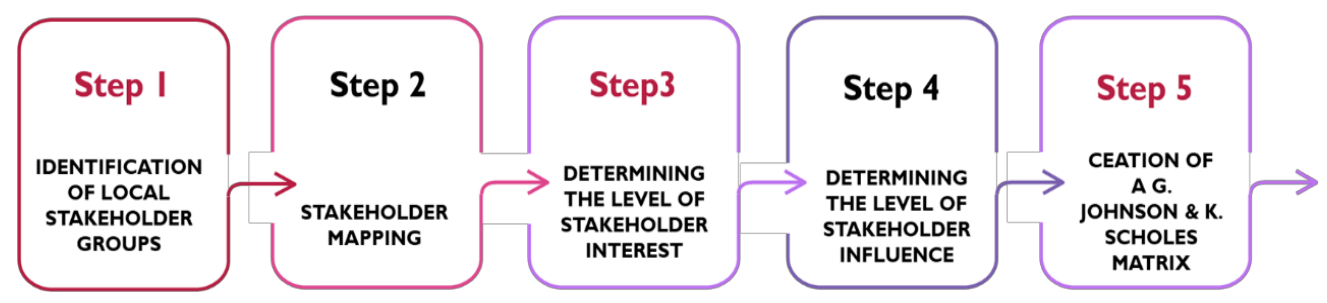

Fig. 6. Stakeholder mapping algorithm Source: own study.

The first step is to identifythe types of facilities and groups of local stakeholders present in the area. This is done based on available documentation of the company concerned. Within the framework of such documentation, we can consider, among others non-financial reports, integration reports, company strategies, or local development plans. The project team's knowledge of the site is also important. On the basis of this information, the individual local stakeholder groups are identifiedasthe hosts (ICMM 2014). An example is shown in Table 2.

Table 2. Table showing the link between the types of objects occurring in the mining area and the types of hosts.

\begin{tabular}{|c|c|}
\hline $\begin{array}{r}\text { TYPE OF OBJECTS } \\
\text { IN THE MINING AREA }\end{array}$ & $\begin{array}{r}\text { HOST (LOCAL } \\
\text { STAKEHOLDERS) } \\
\end{array}$ \\
\hline residential buildings & residents \\
\hline public buildings & \multirow{7}{*}{ local administration } \\
\hline schools & \\
\hline kindergartens and crèches & \\
\hline firestations & \\
\hline community, folk, and other cultural centres, etc. & \\
\hline offices of communes, towns, districts & \\
\hline sports and recreation facilities & \\
\hline businesses and shops & investors \\
\hline churches and chapels & priests, parishes \\
\hline \multirow{2}{*}{ roads } & local government \\
\hline & GDDKIA \\
\hline nature protection & GDOŚ \\
\hline monuments & WUOZ in Lublin \\
\hline watercourses (rivers, canals, lagoons) & RZGW in Lublin \\
\hline
\end{tabular}

Source: own study

The next step is stakeholder mapping, i. e., activities consisting of collecting information about individual units. The result of these activities is a table containinginformation about the location, range [ha], name of the town, stakeholders, hosts, accumulation (area), stakeholders representative, telephone, e-mail, address, description, comments.

Step three is a stakeholders' interest survey by the group. Public information is used to identify the level of interest. The easiest way to do this is to conduct a survey of the press materials and media information available on the Internet. It is necessary to create a table in 
which we cancount the number of media mentions incertain overtones: positive, negative, neutral (example Tab. 3).

Table 3. The result of host interest surveys based on media mentions for the selected mining area.

\begin{tabular}{|c|c|c|c|}
\hline \multirow{2}{*}{ HOST } & \multicolumn{3}{|c|}{ THE KIND OF INTEREST } \\
\hline & POSITIVE & NEUTRAL & NEGATIVE \\
\hline RESIDENTS & 12 & 24 & 47 \\
\hline $\begin{array}{c}\text { LOCAL } \\
\text { ADMINISTRATION }\end{array}$ & 3 & & 3 \\
\hline \multicolumn{4}{|l|}{ INVESTORS } \\
\hline PRIESTS, PARISHES & & 1 & \\
\hline \multicolumn{4}{|l|}{ GDDKIA } \\
\hline \multicolumn{4}{|l|}{\begin{tabular}{cc|} 
GDOŚ & (NATURE \\
PROTECTION & \\
\end{tabular}} \\
\hline \multicolumn{4}{|l|}{ WUOZ (MONUMENTS) } \\
\hline \multicolumn{4}{|l|}{ RZGW (WATERS) } \\
\hline MEDIA & & 14 & \\
\hline
\end{tabular}

Source: own study

Step four is to examine stakeholders' impact on the company. The easiest way to measure the level of impact is to carry out a benchmarking exercise among competitive, industry-oriented companies. Then, using the appropriate scale and algorithm of point allocation, we obtain the level of interest of individual stakeholder groups. The result of such actions is a relational table, an example of which is presented in Table 4.

Table 4. The result of stakeholders impact studies based on benchmarking for a selected mining area.

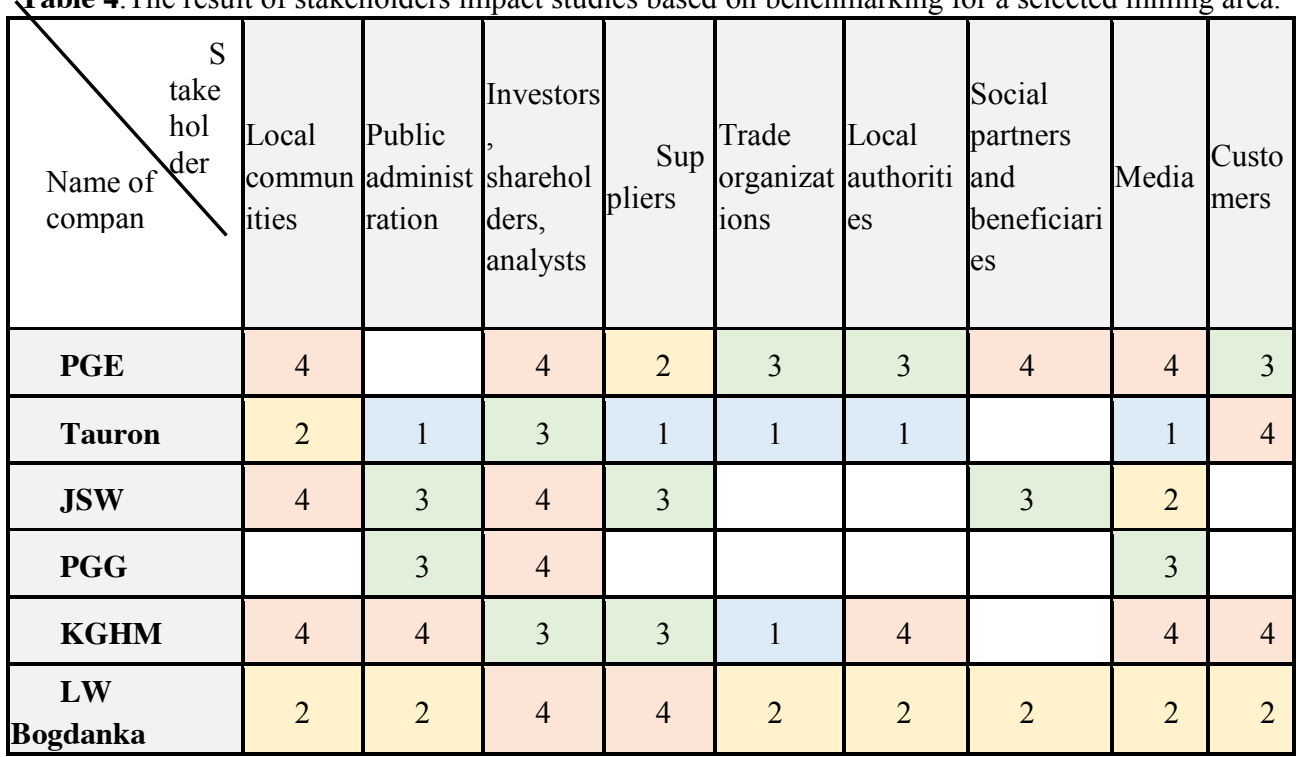

Source: own study 
The final stage of stakeholder identification is the creation of the G. Johnson and K. Scholes matrix, which divides stakeholders into four groups:

- Key stakeholders have a strong interest and influence over the company's situation

- Stakeholders who have a strong interest over the company's situation but limited influence

- Stakeholders who have a little interest and little influence over the company's situation company.

- Stakeholders who have a strong interest and little influence over the

In the previous steps, the level of impact and interest of individual stakeholder groups was determined. The next step is to carry out appropriate calculation activities to match the scale to the oneused in the array system. After the relevant conversions to the matrix, appropriate markings are applied. An example of a completed matrix is shown in Figure 7.
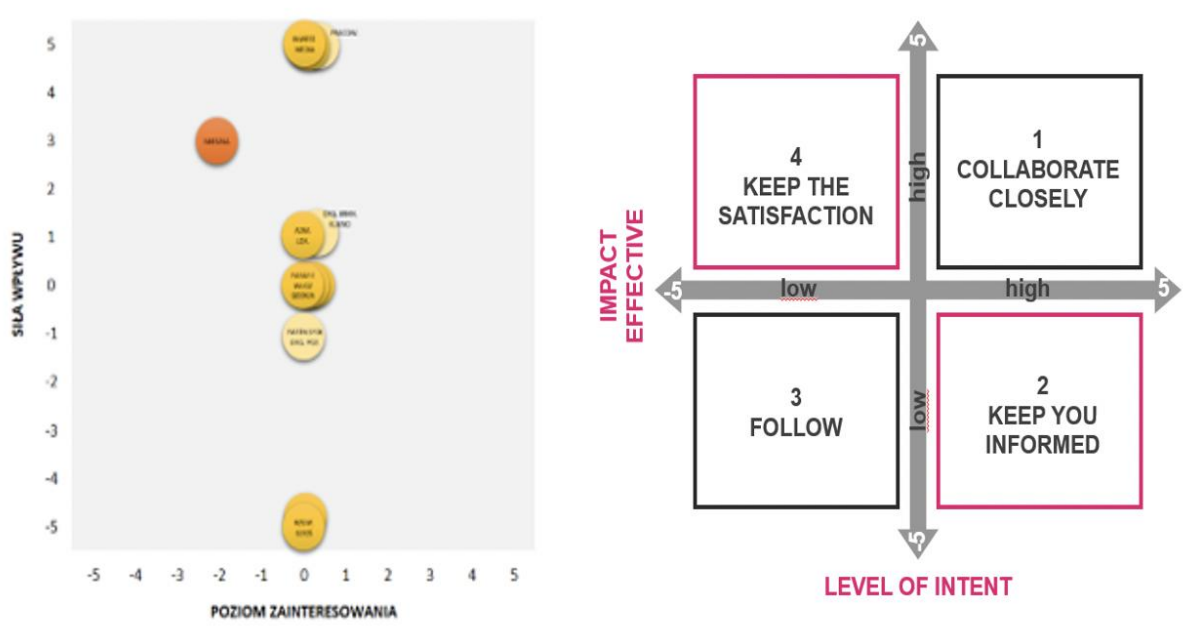

Fig. 7. Johnson-Scholes matrix: (a) on the left, the result of the work for the selected mining area, (b) on the right, the construction of the matrix Source: (a) own study, (b) own study based on.

Based on this study, we receive feedback on stakeholder groups related to the analyzed company, and additionally, we know actions that the company should take about particular groups.

\subsection{Infrastructure identification and possible damage}

Another necessary element for the creation of a relational model is to separate the types of infrastructure existing in the mining area, which is directly related to our stakeholders. Based on literature research and publicly available forums and technical documentation, ten types of infrastructure occurring in the mining areas of the analyzed company were selected and presented in Figure 8. 

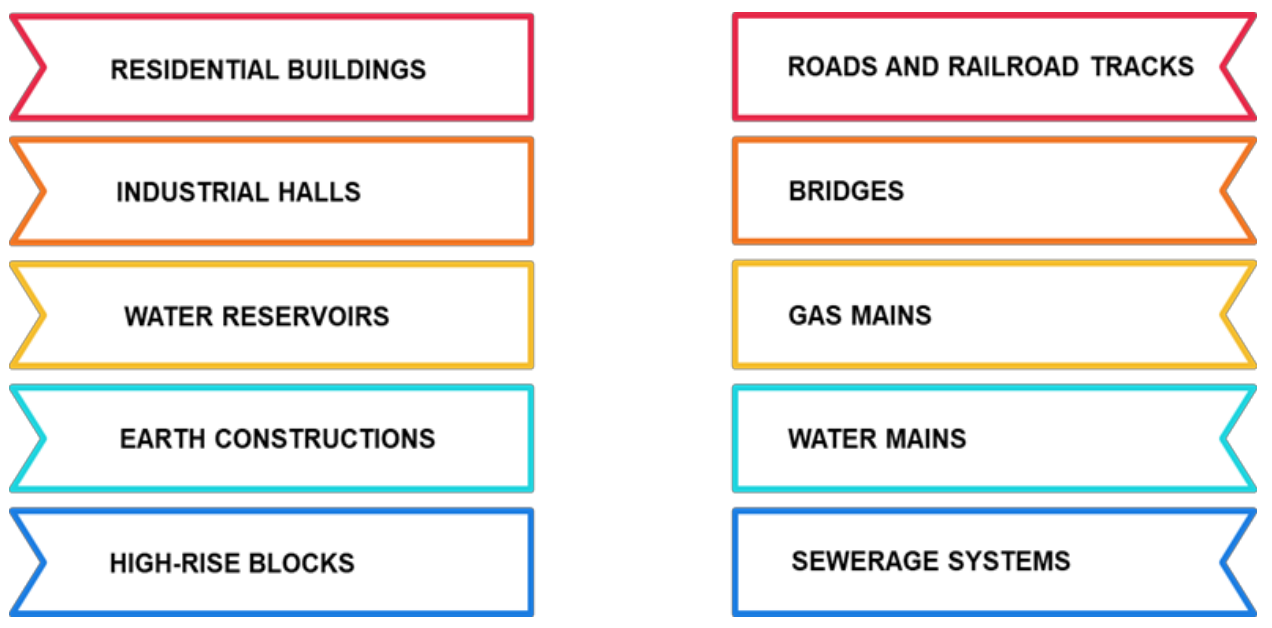

Fig. 8. Types of infrastructure in the selected mining area Source: own study.

The next action is to identify mining damage for varioustypes of infrastructure Based on the article entitled "The way we do it. Mining damages as an element of discomfort in the living conditions of the Upper Silesian inhabitants", a study ofthe types and frequency of individual mining damages was presented. On the basis of this article and other literature, thetypes of damage identified have been assignedto the identified types of infrastructure. This gives the diagram shown in Figure 9. Ascan be seen, the most common mining damage (in relation to the largest number of objects) are cracks and deflections from the vertical.

As the above diagram shows, we distinguish different types of buildings. If we consider a mining damage situation, we need to have adequate knowledge of the building - its structure, strength, possible damage, etc. It was, therefore, decided to split the identified types of infrastructure and assign them to responsible people with appropriate expertise. An Official Receiver is a person responsible for reviewingand verifying the reported damage and who is qualified to do so.

An example of the division of responsibility for different types of infrastructure between the four Official Receivers is shown in Figure 10. As it can be seen, Official Receiver 1 has residential buildings and industrial halls under its responsibility, so these are buildings used directly by human beings. Official Receiver 2 is responsible for water reservoirs, earth constructions, and high-rise blocks. This infrastructure is structurally similar to each other, so the Official Receiver should have an appropriate set of competencies. Official Receiver 3 is responsible for roads, railroad tracks, and bridges that are categorized as transport. Official Receiver 4 is responsible for the transport infrastructure, i. e., gas, water, and sewerage systems. 

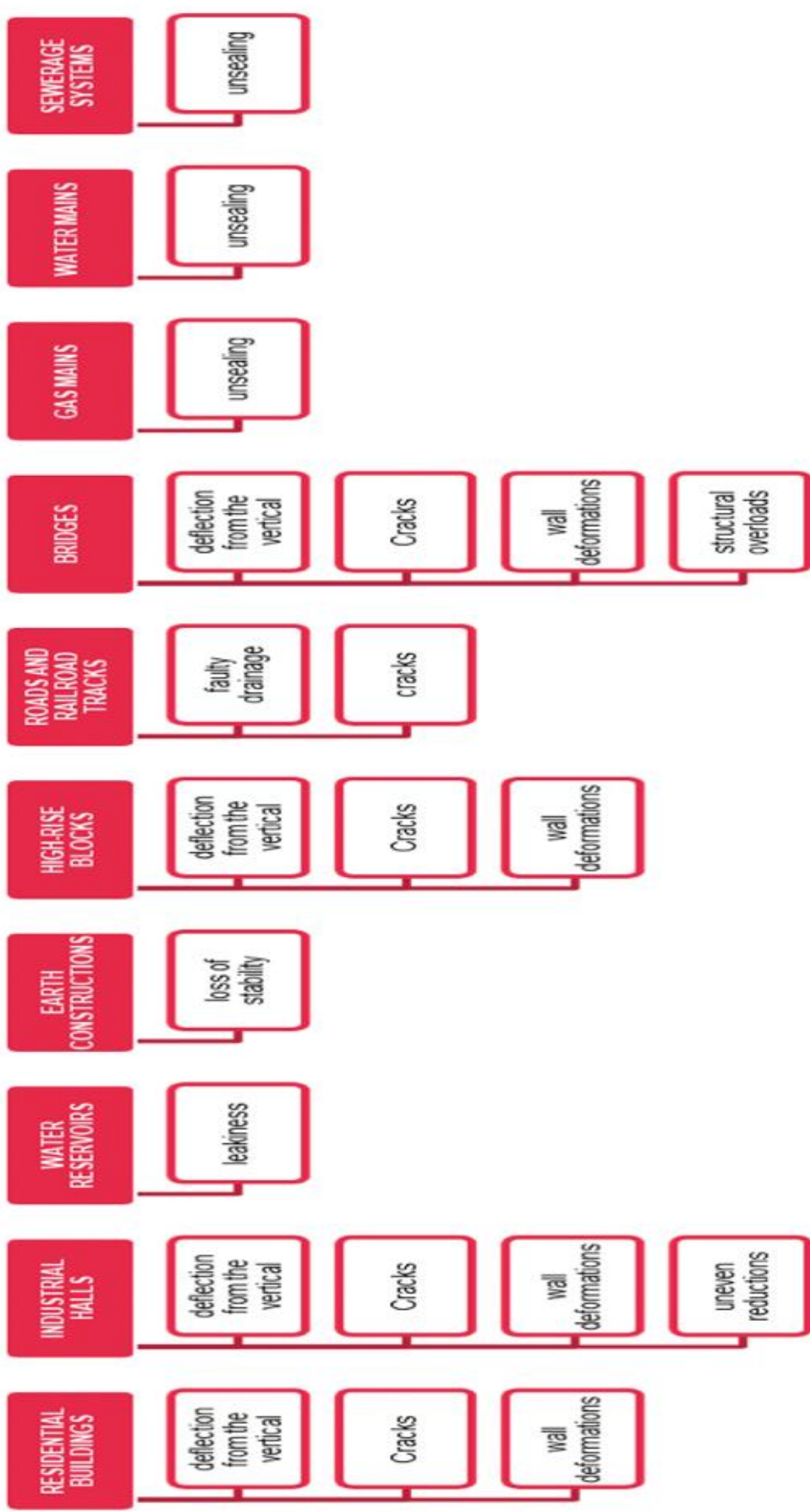

Fig. 9. Identified mining damages for different types of infrastructure Source: own study. 


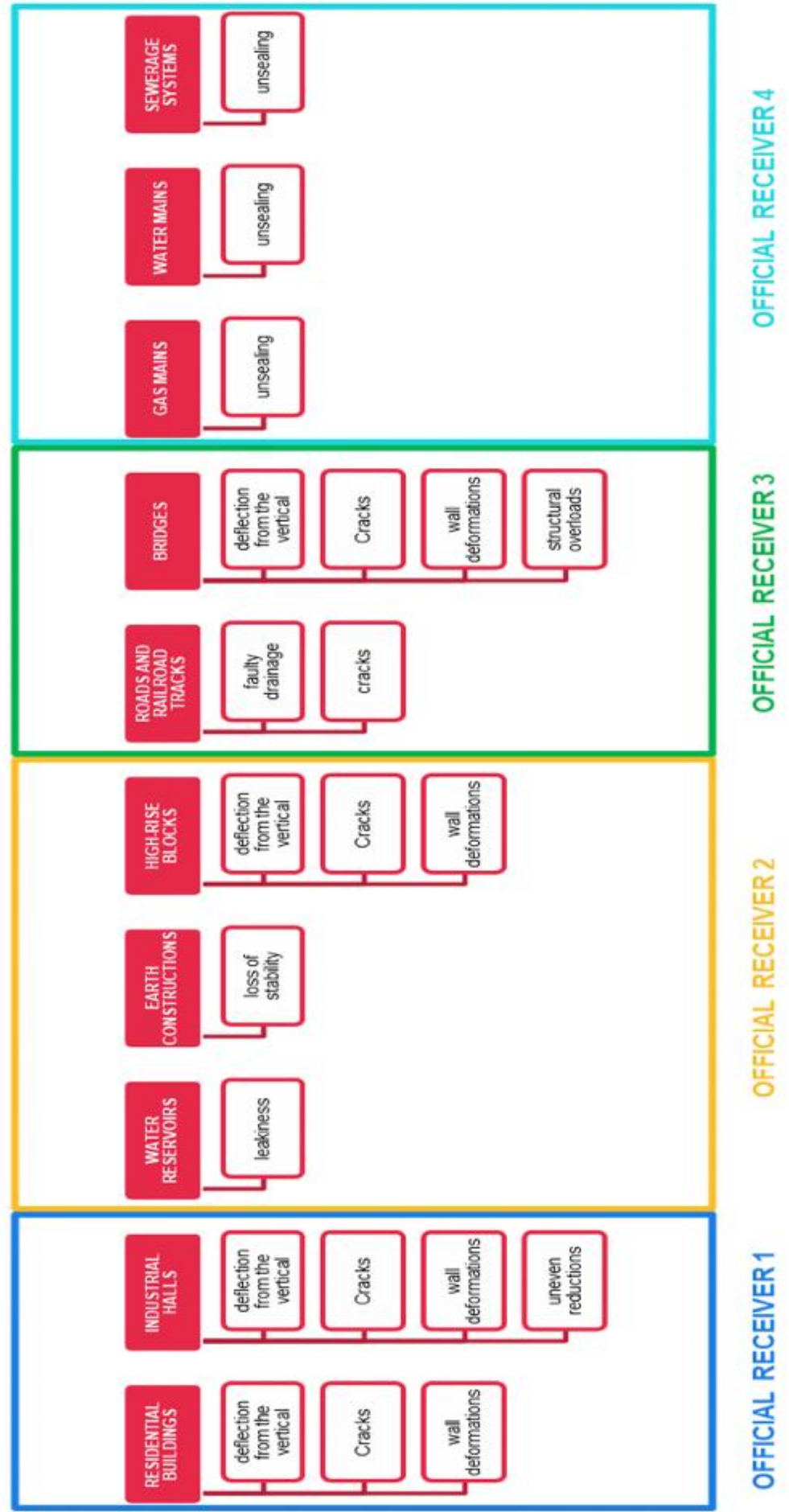

Fig. 10.Example of the division of responsibility for different types of infrastructure for the four Official Receivers Source: own study. 


\subsection{Developing a complaint algorithm for local stakeholders}

On the basis of the data and information obtained in the previous phases of the project, the construction of a local stakeholder complaint algorithm was started. It is presented in three parts in Figures 11, 12, and 13. The algorithm starts when a stakeholder wants to report mining damage. He/she has a choice of one of two paths: a special hotline (right side of Figure 11) or an application form on the website (left side of Figure 11). In the case of the form, the declarant shall fill in the following fields with all basic information: contact details, type of infrastructure, and damage. In the case of the hotline, the same questions are asked by the consultant, and a special application form is filled in manually. In the diagram, the rectangle is the main activity, and the rounded rectangle is the necessary documents and a fragment of the conversation scenario.

After passing one of the two chosen paths, the algorithm is merged to lead the application to the appropriate Official Receiver (Fig. 12 ). The allocation to the person responsible for verifying the correctness of the declaration is carried out according to the allocation of types of infrastructure to the skills of the Official Receivers presented in subsection 4. 2 in Figure 10.

As a result of the information filled in or collected during the interview, the consultant can complete the specific application form and assign an individual number to it. During the conversation, it is given in words, in the case of a form, it is generated automatically. At the end of the interview or when the form is closed, an e-mail is sent to the applicant containing all the information collected from him/her during the interview and an approximate time for processing the application. A diagram of the algorithm's part A procedure and termination is shown in Figure 13. The structure of the next part of the algorithm depends on the type of infrastructure and thus the assigned Official Receiver. It is therefore possible to have one of four patterns of conduct that differ in the time of processing or the number of loopholes.

\subsection{A scheme for dealing with identified mining damage.}

Figures 14 and 15 present a diagram of the condact of the $1^{\text {st }}$ Official Receiver with identified mining damage. It's quite a complicated process. But most importantly, the maximum application processing time is assumed depending on the capabilities of the analyzed company. Individual colors are periods, so from the top, we have 1,7,20 days, etc. The maximum time (last line), in this case, is 3 months. The system shall take into account all the possible routes of action notified. This includes checking the correctness of the application, the departure of the Official Receiver to inspect and measure the infrastructure and damage or an appeal against the first decision, and the need to reconsider the application. 


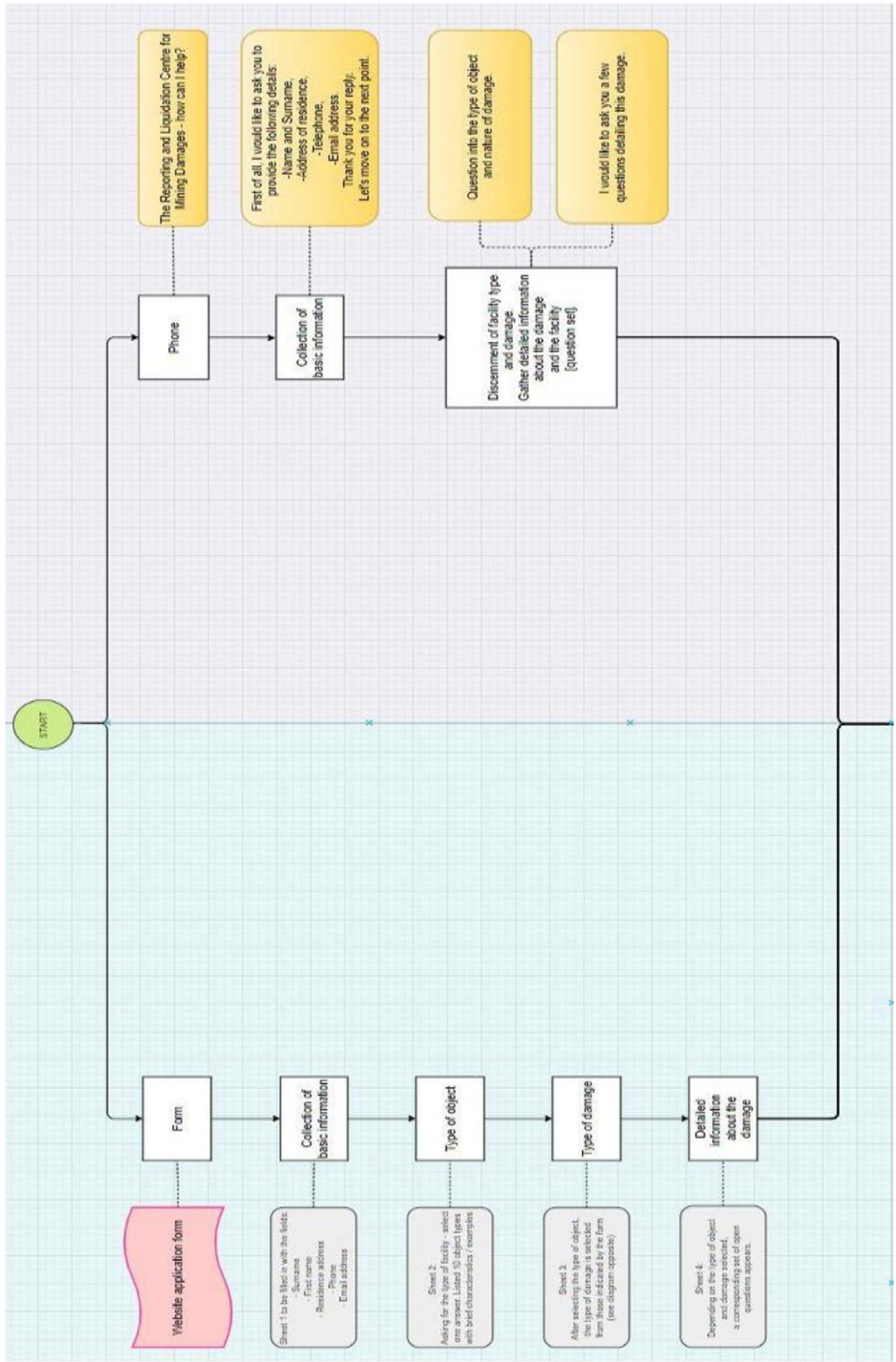

Fig. 11.Complaint algorithm for local stakeholders - Part 1 Source: own study. 


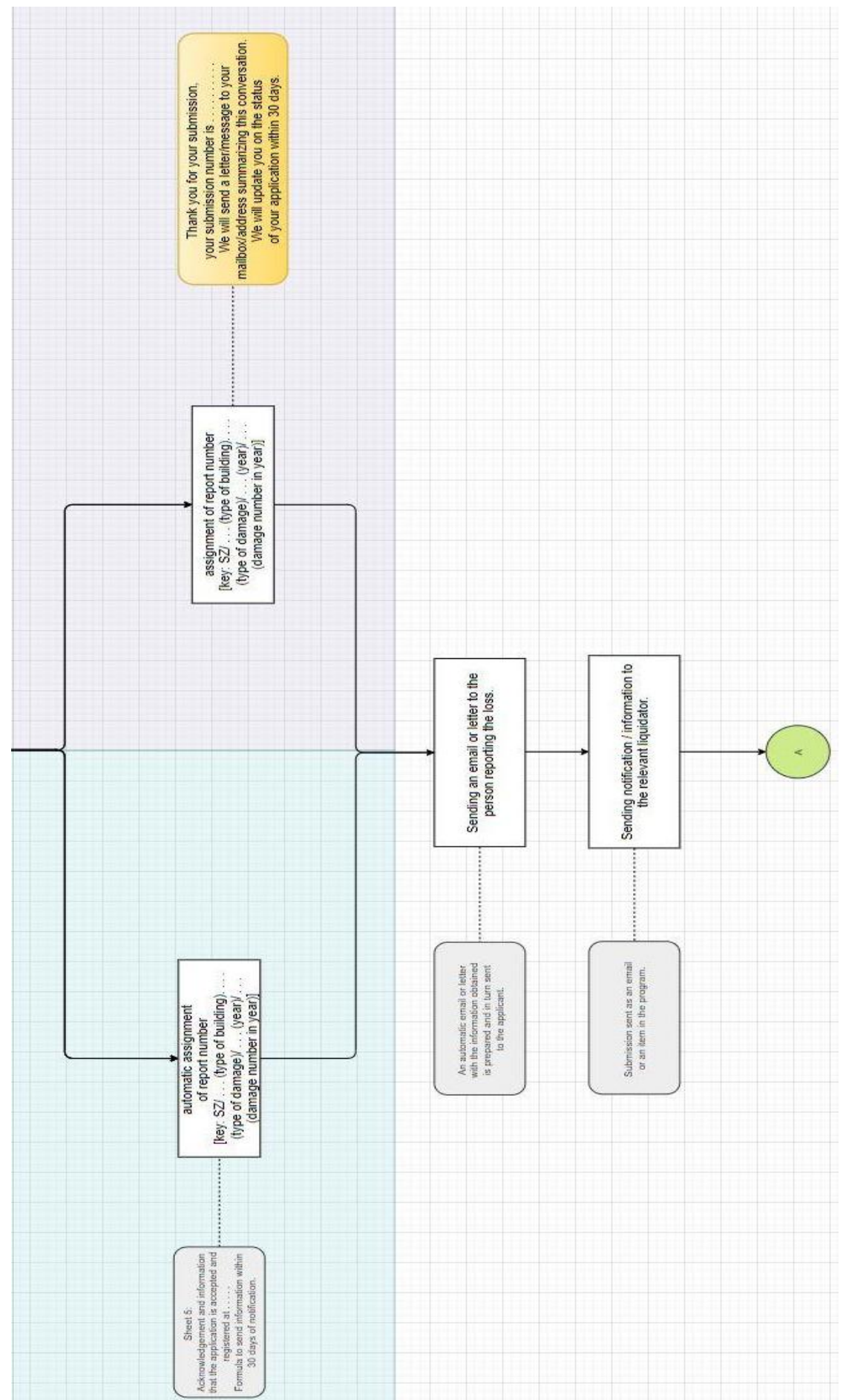

Fig. 12. Complaint algorithm for local stakeholders - Part 2 Source: own study. 


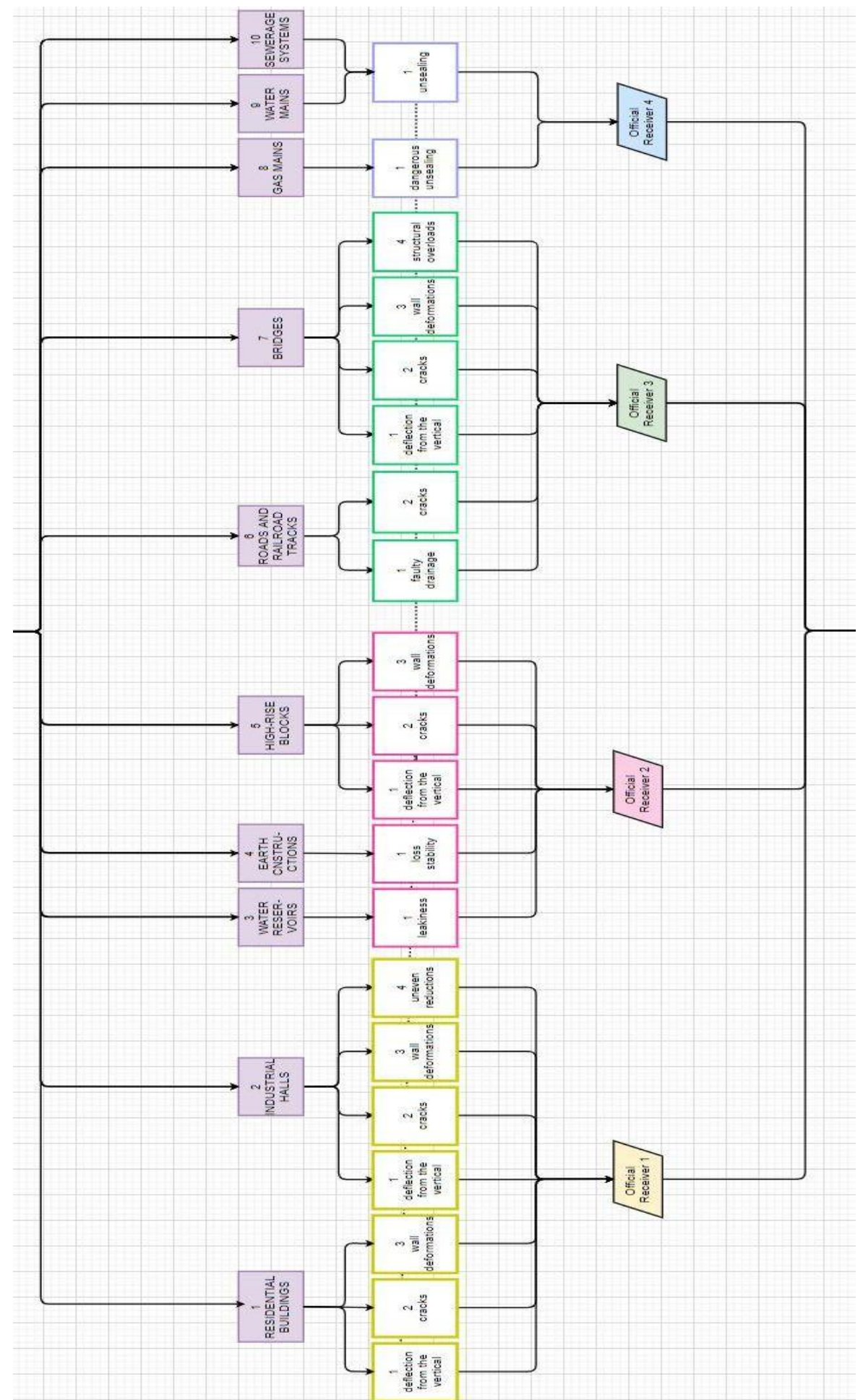

Fig. 13. Complaint algorithm for local stakeholders - Part 3 Source: own study. 


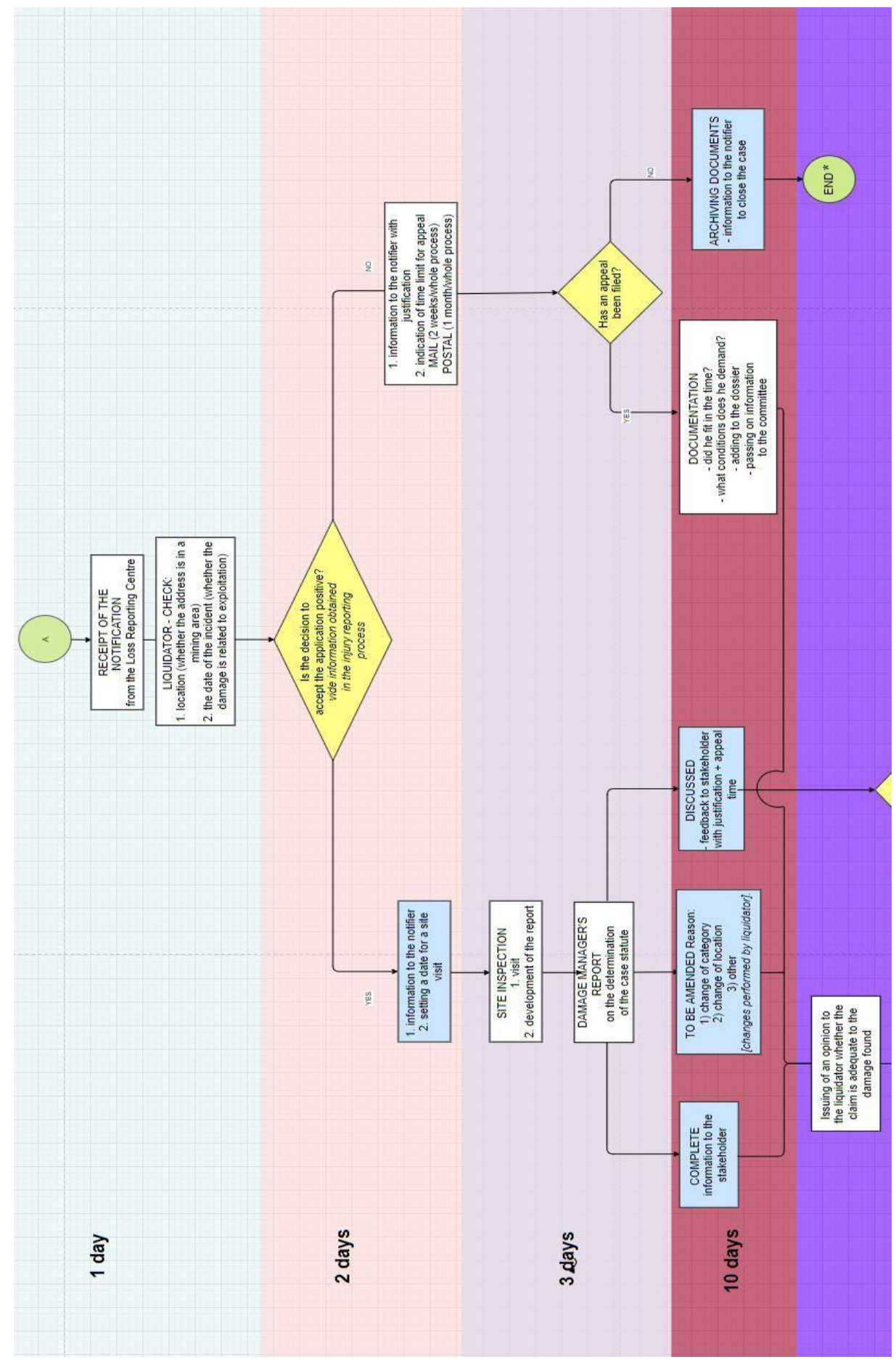

Fig. 14. Scheme for dealing with identified mining damage $-1{ }^{\text {st }}$ Official Receiver- part ASource: own study. 


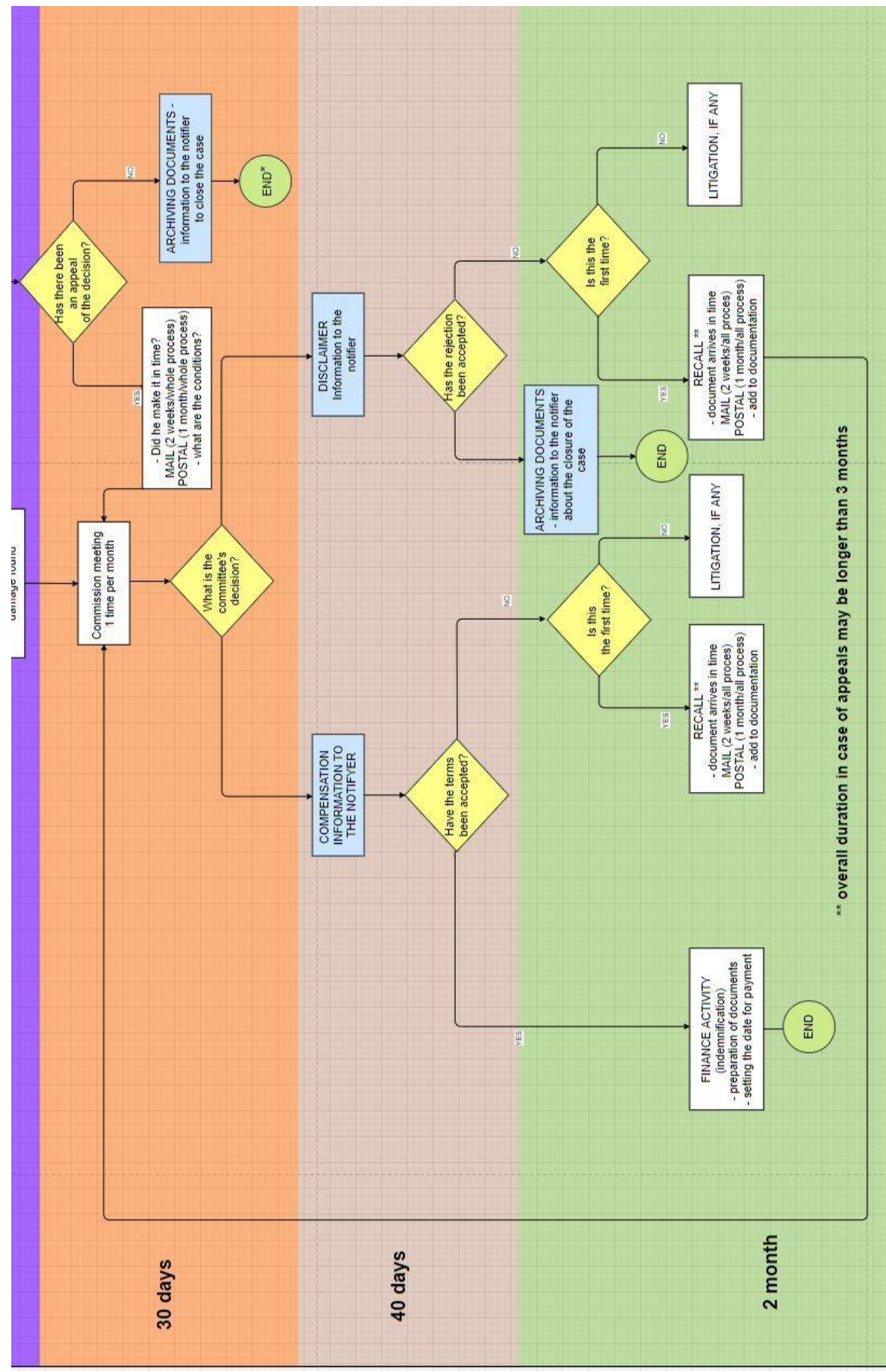

Fig. 15.Scheme for dealing with identified mining damage - 1 Official Receiver - part B. Source: own study. 


\section{Summary}

The growing excess of supply over demand, largely due to increasing globalization including communication, requires companies to take increasingly sophisticated and extensive measures to operate efficiently on the market. Among such solutions, the concepts of relational marketing and in a broader and more far-reaching sense, sustainable development have evolved in recent years.

Both are based on an appropriate, comprehensive measurement of the needs of customers and, more broadly, of stakeholders, and further, through appropriate segmentation and mapping activities, they assume in their business plansthe construction of activities that take into account these needs, not only directly - relatedto the product, but also indirectly -through world-view. This results in the direct involvement of customers in the operation of the company throughout its entire life cycle, as well as in the full life cycle of each of its business projects.

The algorithm, which is the result of work done in the framework of the presented project, is based on the knowledge and experience of the authors, based on the implementation projects, and in accordance with the Servqual methodology, with parallel consideration, according to the project management triangle, of elements of scope, finance, time and quality. The presented algorithm allows for the identification of local stakeholders (hosts) and types of objects presentin the area of activity of the mining company. Then combining the two elements on the basis of their characteristics, a two-path host damage reporting scheme was developed, including all the information a company needs to know to properly identify and address a claim. The final step is how to deal with the reported injury, which takes into account the different paths: the legitimate reporting of the injury, the occurrence of an unfounded report, and appealing of the decision. Specific steps and decisions are placed in precise time frames, which allows to shorten the processing time to a maximum of 3 months. This algorithm has been prepared as part of a business project and is currently being implemented ata mining company in Poland.

\section{References}

1. D.Beg,G.Vernasca, S.Fischer, R.Dornbusch Mikroekonomia.(PWE, Warszawa. 2014).

2. P.A.SamuelsonEkonomia.(Rebis, Poznań. 2012).

3. P.Drucker Landmarks of Tomorrow.(Harper and Row, New York. 1959).

4. S.Biner, D.Boom Building Knowledge into Strategy: Making Sense of a New Perspective, Long Range Planning, 32, (1982).

5. J.Culliton The management of marketing costs.(Harvard University, Boston. 1948).

6. Ch.Gronroos,V. Quo Marketing? Towards a Relationship Marketing Paradigm, Journal of Marketing Management, (1977).

7. L.L.Berry, A.Parasuraman Marketing Services: Competing Through Quality.(Free Press, London. 1981).

8. J.Anton Customer Relationship Management.(Prentice-Hall, London. 1996).

9. T.Morden Element of Marketing.(Prentice-Hall, London. 1991).

10. J.D.Lenskold Marketing ROI. The Path to Campaign, Customer and Corporate Profitability.(McGrawHill, New York. 2003).

11. A.Fornalczyk, J.Choroszczak, M.Mikulec Restrukturyzacja górnictwa węgla kamiennego - programy,bariery, efektywność, pomoc publiczna, (2012). 
12. P.Bogacz Propozycja selektywnego systemu bezpośredniej dystrybucji i logistyki węgla kamiennego dosegmentuodbiorcówindywidualnych w Polsce,Logistyka, 6, (2014).

13. P.Bogacz Segmentacjarynkuodbiorcówindywidualnych węgla kamiennego w Polscenapotrzebyopracowaniaefektywnego systemu dystrybucji, Kraków, (2018).

14. P.BogaczTrendy i wyzwania CSR a ich uwzględnienie w polskimgórnictwie, GospodarkaSurowcamiMineralnymi,32/2, (2016).

15. L.GawlikWęgieldlapolskiejenergetyki w perspektywie 2050 roku analizyscenariuszowe, GIPH, (2013).

16. T.Huzarewicz, K.Włodarczyk,I.KrawczoskaKonkurencyjnośćcenpolskiego węgla narynkukrajowym,materiatykonferencyjne XXVII KonferencjiZagadnieniaSurowcówEnergetycznych i energii $w$ gospodarcekrajowej, Kraków, (2013).

17. A.JaśkowskiWieloaspektowaoptymalizacjailościowojakościowejstrukturyprodukcjigrupykopalńwęgla kamiennego (spółki, holdingu) W dostosowaniu do potrzebodbiorców,Archives of MiningSciences, 43 (4), (2004).

18. M.Jaszczuk, J.Kania Coal production costs components and coal price as crucial factors in the designtion of coal output,Archives of Mining Sciences, 53 (2), (2008).

19. K.Stala-SzlugajSpalanie węgla kamiennego w sektorzekomunalno-bytowym wpływnawielkośćniskiejemisji,OchronaŚrodowiska,13, (2011).

20. P.Bogacz, M.Migza Environmental management reporting in Polish mining companies in the context of World CSR trends, E3S Web of Conferences, 10, (2016).

21. P.BogaczMożliwościwykorzystaniamarketingurelacyjnego w tworzeniuprzewagikonkurencyjnejproducenta węgla kamiennego w sektorzeodbiorcówindywidualnych,Materiaty XVIII SzkołyEksploatacjiPodziemnej, Kraków, (2009).

22. P.Bogacz Optymalizacja dystrybucji i logistyki w ujęciubezpośrednim do segmentuodbiorcówindywidualnych,Logistyka,4, (2015). 